\title{
Nitrogen Metabolism and Antioxidant System in Young Plants of Parkia pendula Submitted to Drought
}

\author{
Oliveira B. Tamires ${ }^{1}$, Karollyne R. S. Silva ${ }^{1}$, Dielle T. F. Teixeira ${ }^{1}$, Milena P. Moraes ${ }^{1}$, Glauco A. S. Nogueira ${ }^{1}$, \\ Ataíde L. S. Wander ${ }^{1}$, Bruno M. Maltarolo ${ }^{1}$, Ellen G. S. Lima ${ }^{1}$, Nascimento R. Vitor ${ }^{1}$ \\ \& Oliveira Neto F. Cândido ${ }^{1}$ \\ ${ }^{1}$ Institute of Agrarian Sciences, Universidade Federal Rural da Amazônia, Brazil \\ Correspondence: Glauco A. Nogueira, Institute of Agrarian Sciences, Universidade Federal Rural da Amazônia, \\ Avenida Presidente Tancredo Neves, No 2501 Bairro, Terra Firme, Cidade, Belém, Pará, Brazil. Tel: \\ 55-21-999-044-368. E-mail: glauand@yahoo.com.br
}

Received: August 23, 2018

Accepted: September 27, $2018 \quad$ Online Published: December 15, 2018

doi:10.5539/jas.v11n1p459

URL: https://doi.org/10.5539/jas.v11n1p459

\begin{abstract}
The (Parkia pendula (Willd.) Benth. ex Walp.) species most know as visgueiro is a native specie from the Amazon region, belongs to the family Fabaceae-mimosoideae and has been scientifically studied because it is used in landscape projects and the restoration of degraded areas. Intrinsic responses of this species due to water stress is still very superficial, lacking a larger scientific approach in nitrogen and oxidative parameters. For this, a greenhouse experiment was set up in the Federal Rural University of Amazon with seedlings, where they were submitted to water restriction. The experimental design was completely randomized in a $2 \times 3$ factorial design (control and water deficit, and three evaluation times), with 5 replications, totaling 30 experimental units. The results showed that the RWC reduced during the experiment from $73.5 \%$ to $52.99 \%$, evidencing a lower amount of water in these plants. This condition caused the plants to respond positively to the increase of antioxidant enzymes (catalase, APX and SOD), making the plant defense system efficient. As well as for some variables of nitrogen metabolism. The results showed that the RWC reduced during the experiment from $73.5 \%$ to $52.99 \%$, evidencing a lower amount of water in these plants. This condition caused the plants to respond positively to the increase of antioxidant enzymes (catalase, APX and SOD), making the plant defense system efficient. As well as for some variables of nitrogen metabolism. The species in this experimental condition was considered as sensitive to the water stress condition.
\end{abstract}

Keywords: azoto, enzymes, visgueiro

\section{Introduction}

The Amazon is considered a region with high rates of deforestation and high consumption of wood. This has led to a marked decrease in forest species. Parkia hangs up (Willd.) Benth. ex Walp. It is among these species (Silva et al., 2014).

It is a tree of significant size, 20 to $30 \mathrm{~m}$ high, unmistakable by the tabular aspect of its canopy. The shaft is cylindrical, rectilinear, occasionally with small sapopemas; the leaves are composed; the inflorescence is of the capitular type, with dark red flowers; the fruits are hung by long peduncles and are of the vegetable type, exuding, when ripe, a viscous resin; the seeds are small, rounded and long (Loureiro et al., 2000). It is widely used in construction and shipbuilding (Souza et al., 1997), taboos, boxwood, slabs for plywood and canoes (Loureiro et al., 2000). It occurs naturally in the states of Pará, Amazonas, Acre, Mato Grosso, Rondônia and Maranhão (Souza et al., 1997). Besides these functions, they have been indicated for the recovery of degraded areas in the Amazon because they present, among other characteristics, rapid growth over open areas and economic potential (Hopinks, 1986; Oliveira et al, 2006).

Water is one of the most fundamental natural resources for the development and growth of plants, since it contributes to the maintenance of the activities of biological molecules, cellular, tissues and organisms (Marenco \& Lopes, 2005). Once its absorption in plants is limited, it triggers a series of implications that can lead to tolerance or sensitivity. Knowing the biochemical characteristics of this species under conditions of water stress, broadens the horizons to base it with a forest species of great value in economic, social and environmental aspects. The water stress condition decreases the availability of nitrogen in plant tissues, considering that this 
element is constituent of structures such as proteins, coenzymes, nucleic acids, chlorophyll, pigments and by-products (Ferreira et al., 2007), essential structures for the growth and development of plants (Pavinato et al., 2008).

Water stress can also generate oxidative stress, due to the stomatal closure, which results in the limitation of photosynthesis. However, this closure does not prevent the photons from being absorbed by the pigments located in the antenna complex. Thus, the energy from the excitation of chlorophyll molecules that has not been used in photosynthesis or eliminated in the form of heat causes a production of reactive oxygen species (ROS), such as superoxide $\left(\mathrm{O}_{2}^{-}\right)$, hydrogen peroxyde $\left(\mathrm{H}_{2} \mathrm{O}_{2}\right)$ and singlet oxygen $\left({ }^{1} \mathrm{O}\right)$ (Assada, 1999). These ROS are highly harmful to the plant as they can react with any molecule in the cell, such as proteins, deoxyribonucleic acids and lipid peroxidation causing a cellular disorder (Soares \& Machado, 2007).

In order to clarify the responses of this plant to water stress, the objective was to evaluate the nitrogen and antioxidative behavior of the species Parkia pendula.

\section{Material and Methods}

\subsection{Location and Experimental Conduction}

Developed in a greenhouse, from March to August 2015, using visgueiro seedlings (Parkia pendula (Willd.) Benth. Ex Walp) at approximately seven months of age. They were irrigated daily to maintain them in the field capacity for a period of one month (Fernandes \& Sykes, 1968) and $5 \mathrm{~mL}$ of macro and micronutrients were applied in the form of Arnon's nutrient solution before the treatments.

The plants were submitted to two water regimes: irrigated (control) and water deficiency (suspension of irrigation in 10 days), considering time 0 (zero days of water deficiency), time 1 ( 5 days of water deficiency) and time 2 ( 10 days of water deficiency), with 5 replicates, totaling 30 experimental units, each unit being composed of one plant/vessel.

\subsection{Relative Water Content}

The leaf relative water content was evaluated using leaf disks with $10 \mathrm{~mm}$ of diameter and it was carried out in each plant, in which 40 disks were removed and the calculation was done in agreement with the formula proposed by Slavick (1979):

$$
\mathrm{LRWC}=[(\mathrm{FM} 1-\mathrm{DM}) /(\mathrm{FM} 2-\mathrm{DM})] \times 100
$$

Where, FM1 is fresh matter, FM2 is turgid matter evaluated after $24 \mathrm{~h}$ and saturation in deionized water at $4{ }^{\circ} \mathrm{C}$ in dark, and DM is the dry matter determined after $48 \mathrm{~h}$ in oven with forced air circulation at $80^{\circ} \mathrm{C}$.

\subsubsection{Concentrations of Nitrate}

The Cataldo et al. (1975) method was used for the determination of nitrate. The absorbance was determined at $410 \mathrm{~nm}$ and the concentration of nitrate was obtained from a standard curve with increasing concentrations of $\mathrm{NO}_{3}^{-}\left(0,0.5,1.0,2.0,3.0,4.0\right.$ and $\left.5.0 \mu \mathrm{mol} \mathrm{mL} L^{-1}\right)$. The results were expressed in $\mu$ moles of $\mathrm{NO}_{3}^{-} \mathrm{g}^{-1} \mathrm{DM}$ of tissue.

\subsubsection{Nitrate Reductase Activity}

The collection of plants was scheduled at 05:30 AM for the determination of nitrate reductase activity (RN), which was performed in vivo by selecting in the greenhouse. The fully expanded primary leaves were selected from each of the repetitions, according to the method described by Hageman and Hucklesby (1971). The reading was performed at $540 \mathrm{~nm}$ and the result of the activity estimated by producing $\mathrm{NO}_{2}^{-}$in 851 . the reaction middle, expressed in $\mu$ moles $\mathrm{NO}_{2}{ }^{-} \mathrm{g}^{-1} \mathrm{MF} \mathrm{h}{ }^{-1}$ from a standard curve obtained by $\mathrm{KNO}_{2}$ p.a (Sigma).

\subsubsection{Concentrations of Free Ammonium}

$50 \mathrm{mg}$ of lyophilised leaves weighted and placed in test tubes containing the total extract, solution A and solution $\mathrm{B}$ after shaking. The free ammonium concentrations were estimated from the standard curve constructed with (NH4) ${ }_{2} \mathrm{SO}_{4}$ p.a. (Sigma) according to method described by (Weatherburn, 1967).

\subsubsection{Concentrations of Total Soluble Amino Acids}

$50 \mathrm{mg}$ of previously lyophilised leaves weighted then buffered solution and reagent ninhydrin were added. The total free amino acid levels were determined based on a standard curve adjusted from increasing concentrations of a standard mixture of L-glutamine according to the method described by Peoples et al. (1989). 


\subsubsection{Concentrations of Total Soluble Proteins}

Determination of the total soluble proteins was carried out with $100 \mathrm{mg}$ of powder, incubated with $5 \mathrm{~mL}$ of extraction buffer. This was homogenized and kept in agitation for $2 \mathrm{~h}$, and centrifuged to $2.000 \mathrm{~g}$ for 10 minutes at $20^{\circ} \mathrm{C}$. Quantification of the total soluble proteins was carried out at $595 \mathrm{~nm}$ in accordance with Bradford (1976) with albumin bovine (Sigma Chemicals) as standard.

\subsubsection{Concentrations of Glycine Betaine}

$25 \mathrm{mg}$ of lyophilised leaves weighted and $\mathrm{H}_{2} \mathrm{SO}_{4} 2 \mathrm{~N}$ added into the test tubes and KI-I2 iced. A standard curve was used of Glycine-Betaine according to the method of Grieve and Grattan (1983).

\subsubsection{Concentrations of Proline}

$50 \mathrm{mg}$ of lyophilised leaves weighted and placed in the test tubes containing total extract, ninhydrin acid and glacial acetic acid. It was determined through a calibration curve proline and proline result expressed in $\mathrm{mmol} \mathrm{g}^{-1}$ dry matter (DM) according to Bates et al. (1973).

\subsubsection{Antioxidant System}

\section{(1) Extraction}

The extract for the determination of the activity of the SOD, APX and CAT enzymes were obtained from the homogenization in mortar at $4{ }^{\circ} \mathrm{C}$ of $0.1 \mathrm{~g}$ of lyophilized leaf powder and root with $5 \mathrm{~mL}$ of potassium phosphate buffer solution (at $4{ }^{\circ} \mathrm{C}$ ) at $0.1 \mathrm{mM}, \mathrm{pH} 7.0$, containing $0.1 \mathrm{mM} \mathrm{EDTA}$, followed by homogenization for $4 \mathrm{~min}$. The additions of the phosphate buffer were made in a fragmented form, $50 \%$ of the total volume of this solution $(2.5 \mathrm{ml})$ being used in the homogenization for $2 \mathrm{~min}$, after which the other $50 \%$ were immediately added, the mixture being homogenized in time equivalent to the previous one. The homogenate was filtered on nylon tissue and transferred to test tubes, and kept at $4{ }^{\circ} \mathrm{C}$ for two hours, with occasional shaking. The filtered homogenate was centrifuged at $12,000 \times \mathrm{g}$ for $15 \mathrm{~min}$ at $4{ }^{\circ} \mathrm{C}$. The supernatant, the crude extract, was stored in a freezer at $-80^{\circ} \mathrm{C}$ until used in enzyme activity assays.

\section{(2) Superoxide Dismutase}

The SOD activity was determined by inhibition of photoreduction of nitroblue tetrazolium chloride (NTC) according to Giannopolitis and Ries (1977).

\section{(3) Ascorbate Peroxidase}

The APX activity was determined by the method of Nakano and Asada (1981).

\section{(4) Catalase}

CAT activity was determined by the method of Beers Jr. and Sizer (1952) with modifications.

\subsection{Experimental Design}

The experimental design was completely randomized in a $2 \times 3$ factorial scheme (two water conditions: control and water deficit, and three evaluation times), with 5 replications, totaling 30 experimental units.

\section{Statistical analysis of the data}

The experimental results were submitted to analysis of variance (ANOVA), and when significant differences were verified the averages were compared by the Tukey test at the $5 \%$ level of significance. Regression analysis was performed on the variables, whose significance was verified by the F-test $(\mathrm{P}<0.05)$. Statistical analyzes were performed using the Assistat 7.7 program.

\section{Results and Discussion}

\subsection{Relative Water Content}

The plants submitted to water deficiency reduced their relative water content in the mesophyll when compared to the control plants (Figure 1), the values presented in the experimental periods 0,5 and 10 days were $73.5 \%$, $62.47 \%$ and $52,99 \%$ respectively. It was below the percentage of control plants that had an average of $76 \%$.

By obeying the physiological principles, water movement occurs by the potential gradient, and for water to flow, the water potential of the soil must be higher than that of the plant. However, under water deficit, the water potential of the soil is reduced and for roots to absorb water, plants reduce their water potential to continue absorption, this mechanism was observed in Jatropha curcas plants (Moura et al., 2016). This reduction can be attributed to the osmotic adjustment due to the accumulation of low molecular weight organic solutes, as observed in Hymenaea courbaril (Nascimento et al., 2011). 


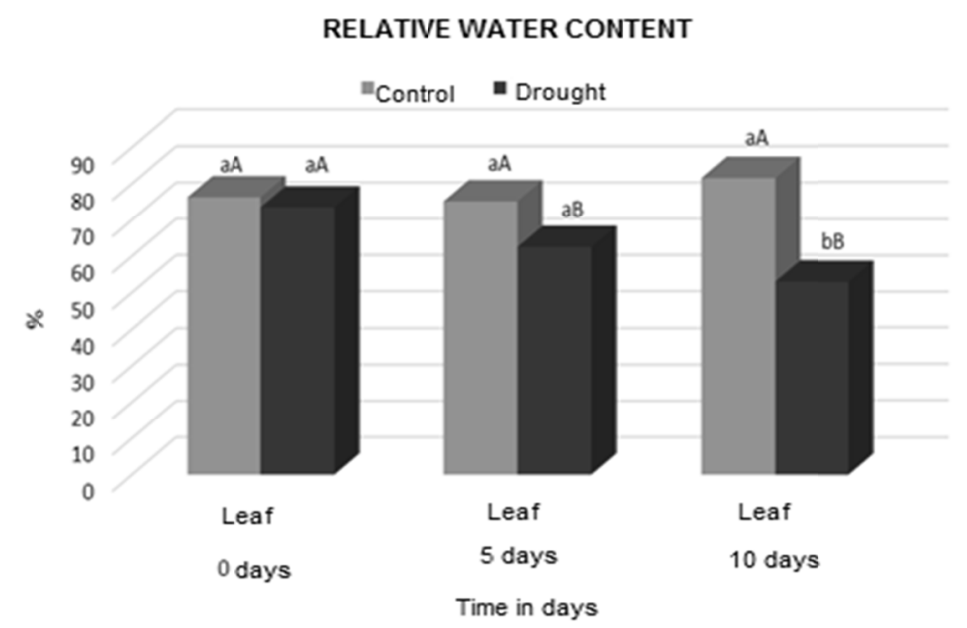

Figure 1. Relative Water Content in Leaves of Visgueiro plants (Parkia pendula (Willd.) Benth. Ex Walp) submitted to 0,5 and 10 days of water deficit. Means followed by the same upper or lower case letter do not differ from one another by the tukey test at $5 \%$ probability. The lower case letters compare the values between the experiment and the upper case letters compare the values between the water regimes

\subsection{Nitrate Content}

Nitrate concentrations decreased in leaves and roots of plants submitted to water deficiency (Figure 2A). Presenting values for sheets 0,$4026 ; 0.26668$ and $0.2015 \mathrm{mmol}$ of $\mathrm{NO}_{3}{ }^{-} / \mathrm{kg} \mathrm{DM}$ and roots $0.0778 ; 0.066$ and $0.0525 \mathrm{mmol}$ of $\mathrm{NO}_{3}{ }^{-} / \mathrm{kg} \mathrm{DM}$ for the times 0,5 and 10 days, respectively. It can be observed a greater concentration in the leaves when compared with the roots, this is due to its accumulation in the leaf vacuoles.

The low relative water content of plants due to water stress (Figure 1) partially explains the low concentrations of nitrate, either in leaves or roots. Nitrogen metabolism depends substantially on the availability of water in the plant (Matos et al., 2012), it is also known that nitrogen metabolism is affected in the initial stages of water deficit as a function of nitrate reductase enzyme sensitivity (Matos et al., 2014).

According to Matimati et al., 2014, nitrogen can regulate the transpiration and mass flow of nutrients, where $\mathrm{NO}_{3}{ }^{-}$modulates the hydraulic conductance of the roots, through the control of the aquaporins, regulation of the effects of $\mathrm{pH}$ and phytormons. Part of the $\mathrm{NO}_{3}{ }^{-}$absorbed is assimilated in the roots, and the rest follows the transpiratory flow, being transported internally in the plants via xylem to the aerial part.

\subsection{Nitrate Reductase Activity}

The results presented for the roots did not present significant differences, presenting low values in this organ. While in the leaves this difference occurred from the 5th day of water stress, as the stress time increased the enzyme lost its functionality (Figure 2B). The values in the leaves of the plants submitted to water deficiency were $0.208 ; 0.1363$ and $0.1458 \mu \mathrm{mol} \mathrm{NO}{ }_{2}^{-} / \mathrm{g} \mathrm{FM}^{-1} / \mathrm{h}^{-1}$ whereas in the plants kept under control were 0.2033 ;

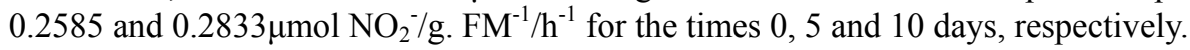

The decrease in the flow of $\mathrm{NO}_{3}{ }^{-}$(Figure 2A) directly influenced the activity of Nitrate Reductase (Figure 2B) in which this enzyme is responsible for its incorporation into the transpiratory stream, where the nitrate reductase initially catalyzes the first assimilated enzymatic step of the nitrogen by the upper plants reducing nitrate (Rhein et al., 2011) to nitrite in roots and/or leaves (Matos et al., 2012; Li et al., 2013). 
Nitrate Concentration

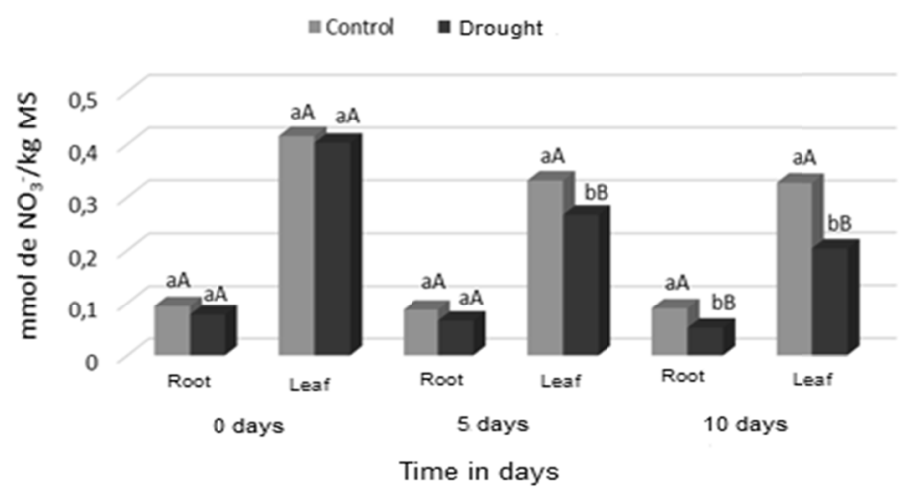

Nitrate Reductase Activity

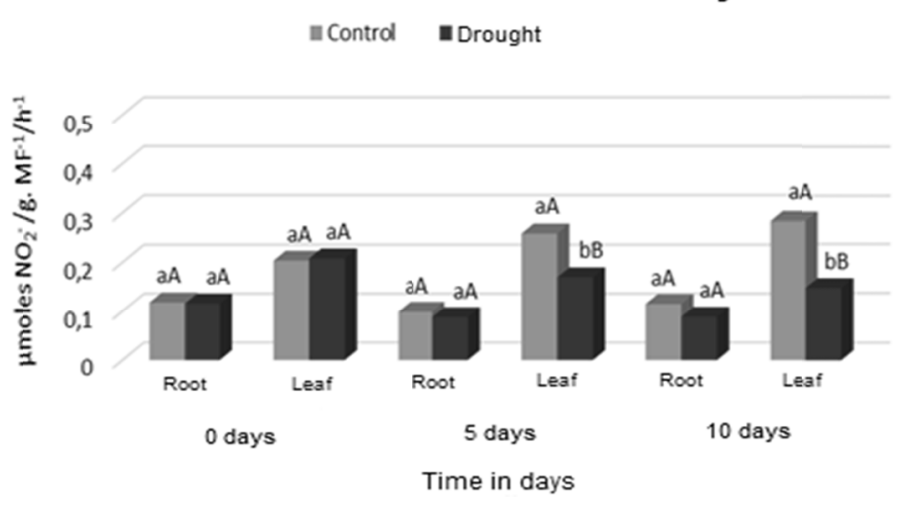

Figure 2. Nitrate concentrations (A) and Nitrate reductase activity (B) in leaves and roots of plants of Visgueiro, submitted to 0,5 and 10 days of water deficit. Means followed by the same upper or lower case letter do not differ from one another by the tukey test at $5 \%$ probability. The lower case letters compare the values between the experiment and the upper case letters compare the values between the water regimes

\subsection{Free Ammonium Content}

A significant increase in ammonium concentration was observed both in the leaves and in the roots of the joist between the water regimes, as the days of water deficiency increased (Figure 3A). The values for leaves submitted to water deficiency were 3.96; 5.5578 and $8.2369 \mathrm{mmol} \mathrm{NH}_{4}{ }^{+} / \mathrm{kg}$ DM. For the roots the ammonium concentration in the plants submitted to water deficiency was $5.6925 ; 7.9005$ and $8.5215 \mathrm{mmol} \mathrm{of} \mathrm{NH_{4 }}{ }^{+} / \mathrm{kg}$ of DM for the 0,5 and 10 days of stress, respectively.

According to Lea and Miflin (2011), this increase in free ammonium concentrations in plants subjected to water deficiency may be linked to other routes for the formation of free ammonium, such as the glutamate dehydrogenase $(\mathrm{GDH})$ route, which acts in dependence on NADH, deaminating the Glutamine synthetase and Glutamine synthetase (Glutamine synthetase). In the present study, glutamate and ammonium $\left(\mathrm{NH}_{4}{ }^{+}\right)$and 2-oxyglutarate were added to promote ammonium accumulation due to increased production and reduction of glutamine synthetase activity. Another possible response in the high ammonium concentrations is due to the low energy level for its assimilation, since the assimilation of ammonium into amino acids is more economical in energy terms ( $\mathrm{Li}$, Wang, \& Stewar, 2013) and its accumulation may derive from direct absorption, nitrate reduction, deamination of nitrogen compounds, photorespiratory cycle or biological fixation (Kant et al., 2007).

\subsection{Total Soluble Aminoacids Contents}

For the concentrations of total soluble amino acids in both the leaves and the roots of the plants under stress there were continuous increases as this condition was maintained (Figure 3B). The values for leaves submitted to water deficiency were 44.0202; 50.8175 and $54.6403 \mathrm{mmol}$ of $\mu \mathrm{mol} \mathrm{AA} / \mathrm{g}$ DM. For the roots were 44.7968; 57.4434 and $66.2227 \mu \mathrm{mol} \mathrm{AA} / \mathrm{g}$ DM for the respective stress times $0.5,10$ and 10 days. 
This accumulation of amino acids may be due to the restriction of protein synthesis (Figure 3C) as a function of proteolytic enzymes and changes in water deficiency in phloem tissues, possibly reducing amino acid translocation to other organs (Oliveira, 2005). According to Carneiro (2014), this increase can be considered as a mechanism of plant tolerance to stress, causing the plant to regulate its nitrogen metabolism by reducing its osmotic potential. However, the plant can regain its growth when the environment is favorable because of its amino acid reserves and nitrogen reserves.

\subsection{Total Soluble Proteins Content}

Decreases in concentrations of total soluble proteins occurred in both the leaves and the roots of the plants under stress (Figure 3C). The values for leaves submitted to water deficiency were $12.5059 ; 9.8637$ and $7.3043 \mathrm{mg}$ protein/g DM. For the roots the concentration of amino acids in plants submitted to water deficiency was 5.8336; 4,5008 and 4,3176 mg protein/g DM for times 0,5 and 10 days of stress, respectively.

The protein biosynthesis process is one of the first metabolic events paralyzed after the perception of water stress, where the plant due to its metabolism is impaired and to overcome this lack after the closure of its stomata, initiates the proteolysis, promoting an increase in content of free amino acids, with consequent decrease in protein concentration (Turkan, 2011), as observed in Figures 3B and 3C.
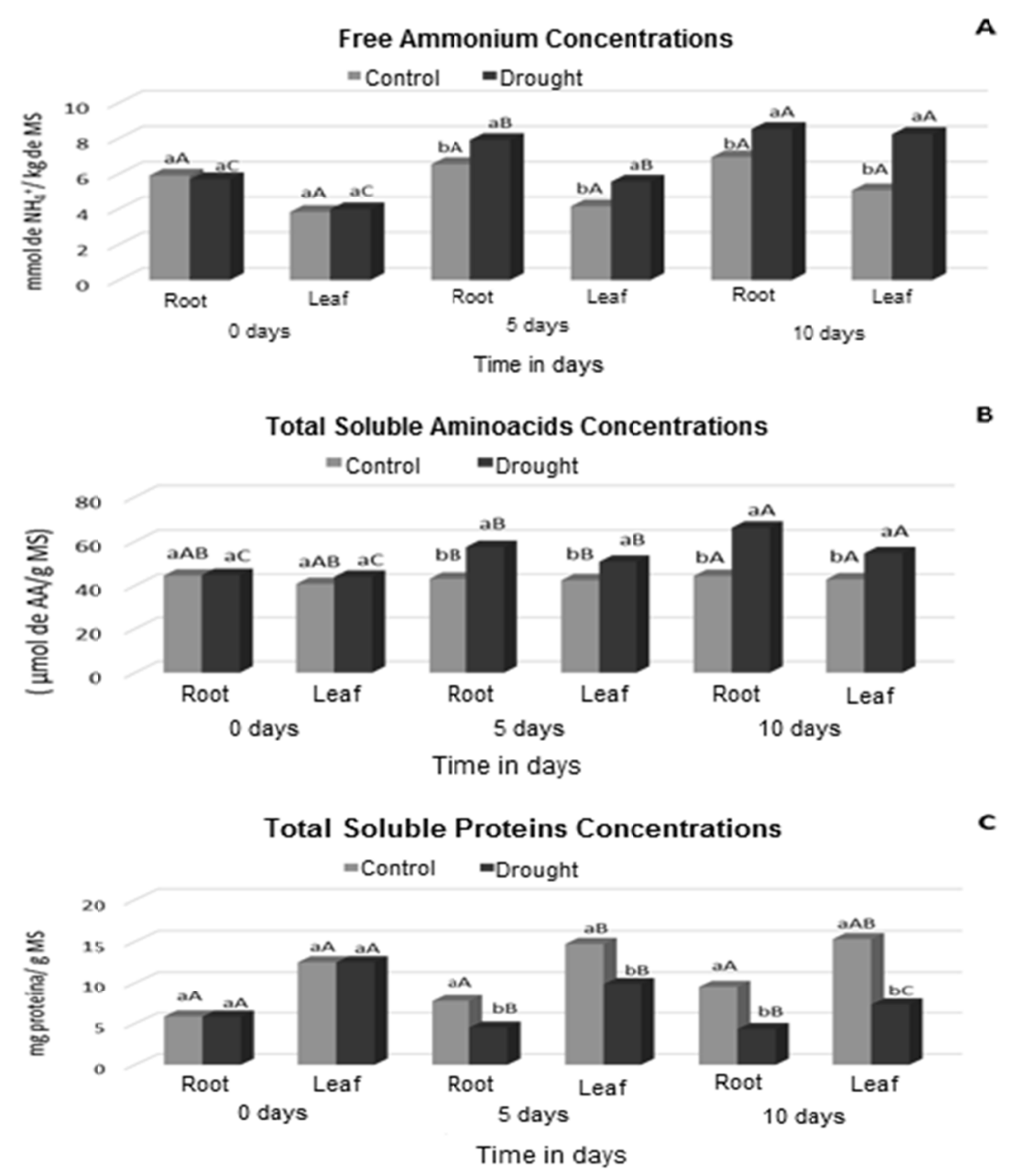

Figure 3. (A), Total Soluble Amino Acids (B) and Total Soluble Proteins (C) in leaves and roots of plants of Visgueiro, submitted to 0,5 and 10 days of water deficiency. Means followed by the same upper or lower case letter do not differ from one another by the tukey test at 5\% probability. The lower case letters compare the values between the experiment and the upper case letters compare the values between the water regimes 


\subsection{Glycine Bethaine Content}

The glycine-betaine concentration increased significantly with the time of water deficiency in the leaves (Figure 4A), differing statistically between the water regimes, the values under stress were $2.5965 ; 3.2024$ and 4.3023 $\mathrm{mg}$ glycine betaine/g DM. It was observed in the roots of the plants under stress that the concentration of glycine betaine was also significantly affected between the water regimes and between the water restriction times, presenting the results of $1.5733 ; 3.039$ and $4.2507 \mathrm{mg}$ glycine betaine/g DM for the 0,5 and 10 day stress times, respectively.

Plants submitted to water stress conditions need to decrease their intracellular osmotic potential to tolerate water restriction, with which this glycine accumulation functions as a nitrogen supply, maintaining the integrity of the membrane under adverse conditions, stabilizing the structures and activities of enzymes of the protein complex avoiding an oxidative degradation caused by the increase of the solutes concentrations by the low availability of water because it is located in the cytoplasm of the cells (Chen \& Murata, 2011; Szabados et al., 2011).

This increase in Glycine-Betaine values is probably due to the formation of total soluble amino acids (Figure 3B) through the degradation of the total soluble proteins (Figure 3C) and the high concentrations of free ammonium (Figure 3A). photorespiration and deamination processes which are essential for the formation of the betaines, and because they do not possess only the osmoprotective function in the cells, this molecule can be synthesized from the choline or the precursors to be used in the metabolic pathway to form compounds bound to the synthesis of the ethylene hormone and the pyruvate molecule, besides being a source of carbon, nitrogen and energy (Munôz-Clares et al., 2004).

\subsection{Proline Content}

The concentrations of the amino acid proline increased in the weed leaves of the stressed plants, as the water restriction time increased (Figure 4B). The concentrations of proline in leaves of plants submitted to water deficiency were $2.4482 ; 2.5626$ and $4.5386 \mathrm{mmol} \mathrm{g}^{-1} \mathrm{DM}$ at times with 0,5 and 10 days of stress, respectively. For the roots, there was a significant increase in the proline concentration in the plants submitted to water deficiency and stress times (Figure 4B), presenting values of $1.2189 ; 3.0826$ and $3.6795 \mathrm{mmol} \mathrm{g}^{-1} \mathrm{DM}$. At times with 0,5 and 10 days of stress, respectively.

This accumulation in proline concentrations provides an important parameter for the selection of resistant plants, and it is common to find that increased levels of proline attenuate the effects of water deficiency (Cvikrová et al., 2013; Filippou et al., 2014). According to these authors, the accumulation occurs by "de novo" synthesis or by the inhibition of the proline oxidation process, which as a consequence of the reduction in protein synthesis and the increase in proteolysis, the protection of the membranes against the deleterious effects caused by the reactive species occurs of oxygen (ROS), preventing the denaturation of proteins, preserving the structure of enzymes. Although there is abundant literature on the accumulation of proline in plants under various types of stress, it is uncertain whether this accumulation always occurs (Ashraf et al., 2011; Szábados et al., 2011).

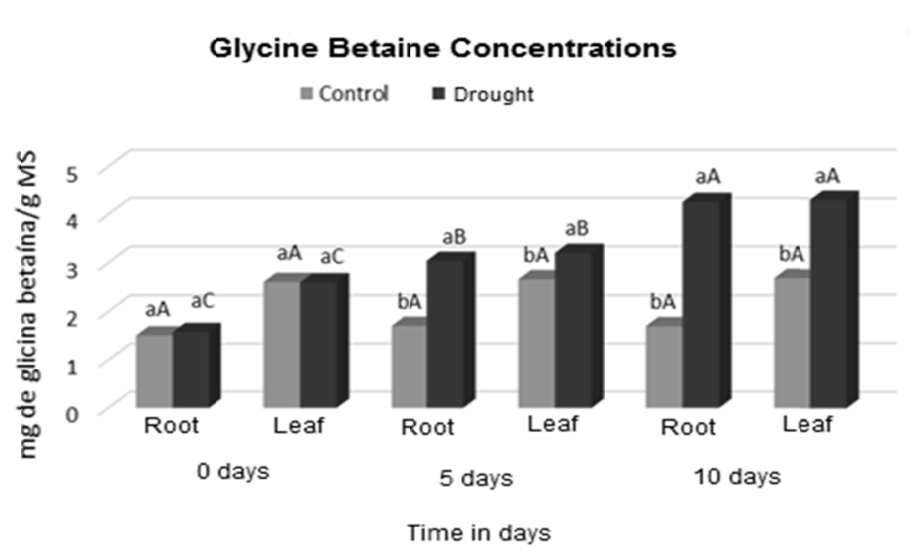




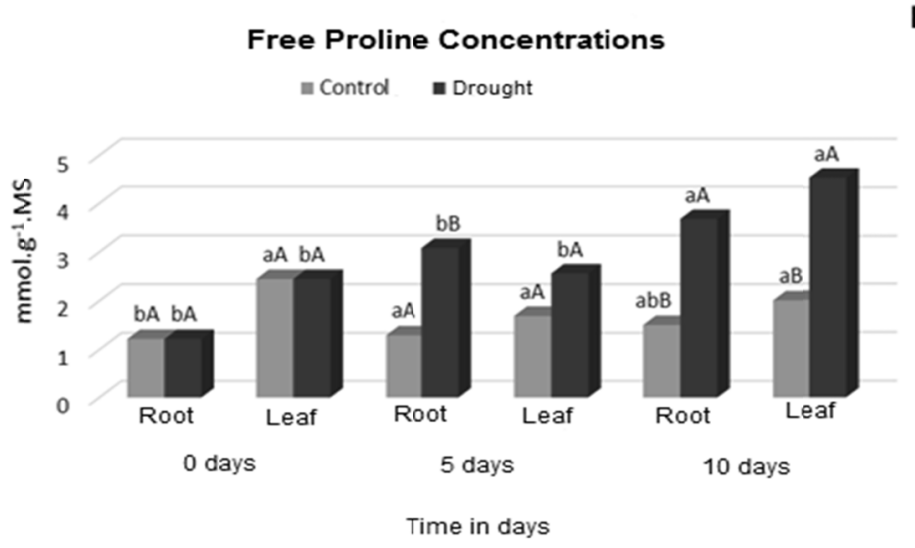

Figure 4. Glycine Betaine (A) and Free Proline (B) concentrations in leaves and roots of Parkia pendula (Willia. Benth. Ex Walp) submitted to 0, 5 and 10 days of water deficit. Means followed by the same upper or lower case letter do not differ from one another by the tukey test at $5 \%$ probability. The lower case letters compare the values between the experiment and the upper case letters compare the values between the water regimes

\subsection{Antioxidant System}

\subsubsection{Superóxido Dismutase (SOD)}

There was a significant increase in the concentration of the enzyme Superoxide Dismutase, both in the leaves and in the roots of the joist between the water regimes and according to the increases of water deficit (Figure 5A). The values for leaves submitted to water deficit were $38.2524 ; 44.6295$ and $48.0991 \mathrm{mg}^{-1}$ protein for the 0,5 and 10 day stress times, respectively, and it was observed that at $10 \mathrm{hn}$ day of stress the enzyme activity increased. For the roots the concentration of SOD in the plants submitted to water deficiency were $43.4047 ; 43.203$ and $50.8990 \mathrm{mg}^{-1}$ protein for times 0,5 and 10 days of stress, respectively.

According to Pompeu et al. (2008), the increase in SOD concentrations is one of the first responses of the plant defense mechanism against oxidative stress, since it is the first enzyme involved in the plant defense system when the cell detects a signal of stress, being responsible for the direct formation of different reactive oxygen species (Sankar et al., 2007). The stress induced a higher activity of SOD, which determines the concentration of $\mathrm{O}_{2}{ }^{-}$and $\mathrm{H}_{2} \mathrm{O}_{2}$, being essential in the defense mechanisms to prevent the formation of $\mathrm{OH}^{-}$radicals, being therefore known to confer tolerance to oxidative stress (Jaleel et al., 2007). The superoxide ions formed during the photolysis of the water in the electron transport chain are converted to $\mathrm{H}_{2} \mathrm{O}_{2}$ by the SOD activity, using water and oxygen by CAT and APX activities (Sood et al., 2011; Carneiro, 2014).

\subsubsection{Ascorbato Peroxidase (APX)}

The activity of the enzyme ascorbate peroxidase increased both in the leaves and in the roots of the joist between the water regimes and as the days of water deficit increased (Figure 5B). The values for leaves submitted to water deficiency were $0.0305 ; 0.0344$ and $0.0387 \mathrm{mmol} \mathrm{min}^{-1}$ for times 0,5 and 10 days of stress, respectively. In the roots of the plants under stress the values presented were $0.0298 ; 0.0338$ and $0.0355 \mathrm{mmol} \mathrm{min}^{-1}$ for times 0,5 and 10 days of stress, respectively.

This increase in APX activity when the plants were submitted to water deficiency conditions suggests that APX played an important role in the control of EROs induced during water deficiency. The APX and other peroxidases, have high affinity, eliminating $\mathrm{H}_{2} \mathrm{O}_{2}$ when in low concentrations, and are the main enzymes responsible for the elimination of $\mathrm{H}_{2} \mathrm{O}_{2}$ in chloroplasts, while CAT acts mainly as peroxisomes (Jaleel et al., 2009). APX because it is present in chloroplasts, mitochondria or ctitosol has high affinity for the substrate, being considered the main enzyme of the ascorbate-glutathione cycle. Ascorbate is used as an enzymatic cofactor, resulting in the formation of dehydroascorbate which is recycled to ascorbate, with glutathione being reduced to electron donation, so that the oxidized glutathione is converted by the NADPH-dependent glutathione reductase (Carvalho, 2012).

\subsubsection{Catalase (CAT)}

In relation to the enzyme Catalase a behavior similar to that of the other enzymes was observed, with an increase in its concentration as the water deficiency increased (Figure 5C). The values for leaves submitted to water 
deficit were $0.0306 ; 0.0356$ and $0.0401 \mathrm{mmol} \mathrm{min}^{-1}$ for times 0,5 and 10 days of stress, respectively. In the root, the concentration of Catalase enzyme in plants submitted to water deficiency was $0.0278 ; 0.0323$ and 0.0346 mmol $\mathrm{min}^{-1}$ for times 0,5 and 10 days of stress, respectively.

Catalase is found in peroxisomes and catalyzes the oxidation of $\mathrm{H}_{2} \mathrm{O}_{2}$ to $\mathrm{H}_{2} \mathrm{O}$ and $\mathrm{O}_{2}$ (Mittler et al., 2002) during photorespiration when the RUBISCO enzyme exerts its oxygenase function, as well as the $\beta$-oxidation of fatty acids in glyoxysomes in tissues that store lipids. Feierabend (2005) explains that catalase is the effective tool in combating high levels of hydrogen peroxide $\left(\mathrm{H}_{2} \mathrm{O}_{2}\right)$, but loses efficacy when there is a small amount of peroxide. However, CAT has a low $\mathrm{H}_{2} \mathrm{O}_{2}$ affinity, being activated only when it is in great periods of water stress. The activity of one or more antioxidant enzymes generally increases in plants exposed to stress conditions and this activity correlates with increased stress tolerance (Pilon et al., 2006). According to Simova-Stoilova et al. (2009), water deficiency produces oxidative stress as a consequence of the increase in ROS and also that many plants are able to cope with this increase, activating the antioxidant enzymes that play a crucial role in cell protection against the damage caused by these potentially toxic compounds to cells (Rishi \& Sneha, 2013).
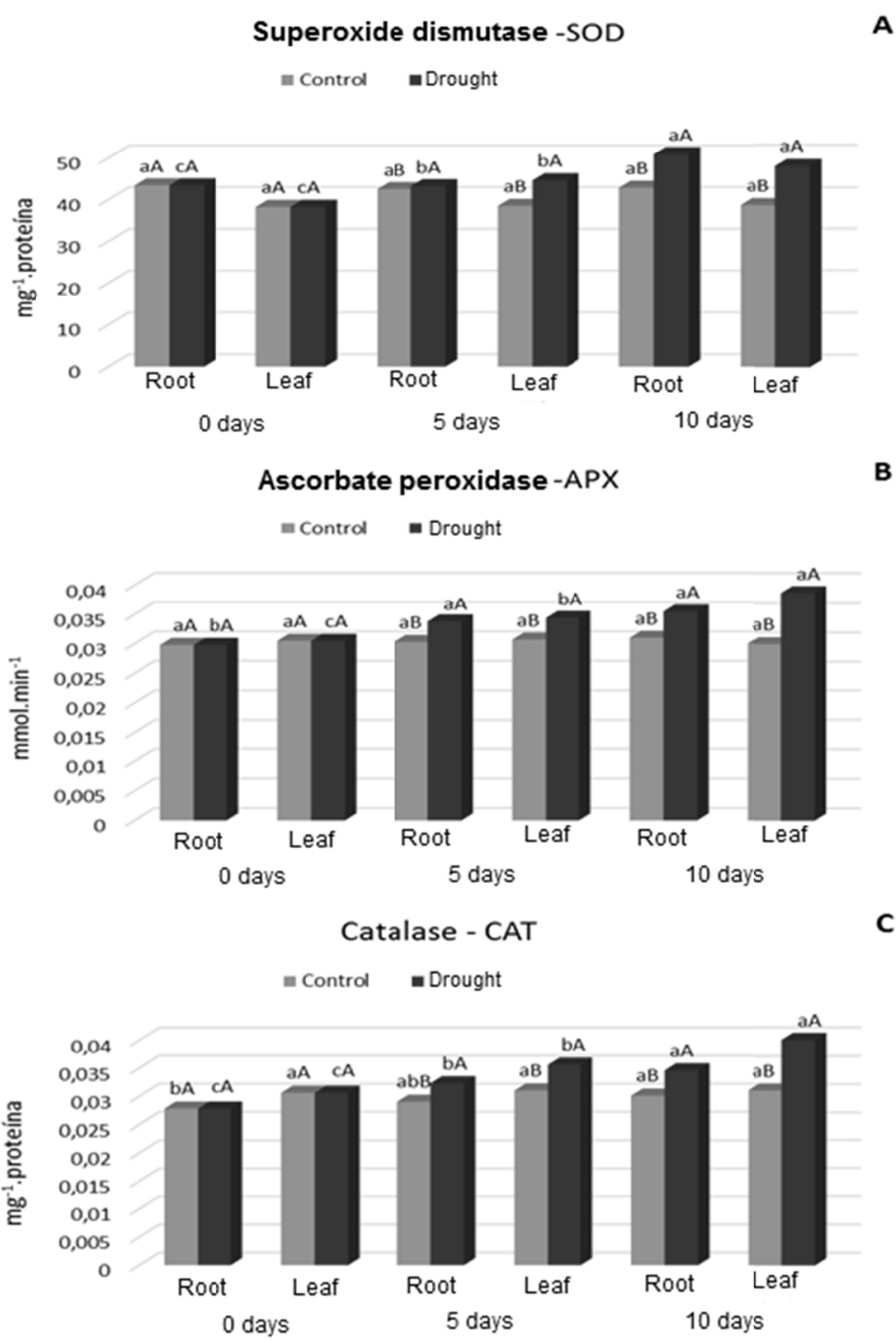

Figure 5. Activity of dismutase of superoxide (A), peroxidase of ascorbate (B) and catalase (C) in leaves and roots of plants of Visgueiro, submitted to 0,5 and 10 days of water deficiency. Means followed by the same upper or lower case letter do not differ from one another by the tukey test at $5 \%$ probability. The lower case letters compare the values between the experiment and the upper case letters compare the values between the water regimes 


\section{Conclusion}

The duration of the experiment after the application of the treatments was sufficient to alter the metabolism of the plants of Visgueiro, concluding that this species in the established condition is very sensitive;

The indicators of nitrogen metabolism and the oxidative system analyzed were efficient to evaluate the metabolic state of the plants of Visgueiro, however it is fundamental to approach other parameters to have a more precise conclusion.

\section{References}

Ashraf, M., Akram, N. A., Alqurainy, F., \& Foolad, M. R. (2011). Drought tolerance: Roles of organic osmolytes, growth regulators, and mineral nutrients. Advances in Agronomy, 111, 249-296. https://doi.org/10.1016/ B978-0-12-387689-8.00002-3

Assada, K. (1999). The water cycle in chloroplasts: Scavenging of active oxygens and dissipation of excess photons. Annual Review of Plant Physiology and Plant Molecular Biology, 50, 601-639. https://doi.org/10.1146/annurev.arplant.50.1.601

Bates, L. S., Waldren, R. P., \& Teare, I. D. (1973). Rapid determination of free proline for water-stress studies. Plant Soil, 39, 205-207. https://doi.org/10.1007/BF00018060

Beers-Junior, R. F., \& Sizer, W. (1954). Aspectrophotometric method for measuring the breakdown of hydrogen peroxide by catalase. Journal of Biological Chemistry, 195, 133-140.

Bradford, M. M. (1976). A rapid and sensitive method for the quantitation of microgram quantities of protein utilizing the principle of protein-dye binding. Analitic Biochemistry, 722, 248-254. https://doi.org/10.1016/ 0003-2697(76)90527-3

Carneiro, M. M. L. C. (2014). Fisiologia de plantas jovens de seringueira cultivadas em diferentes fontes nitrogenadas e sob baixa disponibilidade de água e oxigênio (108f. Tese (Doutorado), Universidade Federal de Lavras, Lavras, MG).

Carvalho, P. A. (2012). Metabolismos do nitrogênio e antioxidante em plantas jovens deseringueira (Hevea spp.) submetidas à baixa disponibilidade de oxigênio na presença de nitrato elou amônio (76f. Dissertação (Mestrado), Universidade Federal de Lavras, Lavras, MG).

Cataldo, D. A., Haroon, M., Schrader, L. E., \& Yougs, V. L. (1975). Rapid Colorimetric determination of nitrate in plant tissue by nitration of salicylic acid. Commum Soil Science and Plant Analysis, 6, 71-80. https://doi.org/10.1080/00103627509366547

Chen, T. H. H., \& Murata, N. (2011). Glycinebetaine protects plants against abiotic stress: Mechanisms and biotechnological applications. Plant, Cell \& Environmental, Weinheim, 34, 1-20. https://doi.org/10.1111/ j.1365-3040.2010.02232.x

Cvikrová, M., Gemperlová, L., Martincová, O., \& Vanková, R. (2013). Effect of drought and combined drought and heat stress on polyamine metabolism in prolineoverproducing tobacco plants. Plant Physiology and Biochemistry, 73, 7-15. https://doi.org/10.1016/j.plaphy.2013.08.005

Feierabend, J. (2005). Catalases in plants: Molecular and functional properties and role in stress defense. In N. Smirnoff (Ed.). Antioxidants and reactive oxygen species in plants (pp. 101-140). Oxford: Blackwell. https://doi.org/10.1002/9780470988565.ch5

Fernandes, B., \& Sykes, D. J. (1968). Capacidade de campo e a retenção de água em três solos de Minas Gerais. R. Ceres, 15, 1-37.

Ferreira, P. A., Garcia, G .O. de, Miranda, G. V., Oliveira, F. G., \& Santos, D. B. (2007). Tolerância da variedade milho ufvm 100 à salinidade avaliada por três métodos. Irriga, Botucatu, 12, 532-544.

Filippou, P., Bouchagier, P., Skotti, E., \& Fotopoulos, V. (2014). Proline and reactive oxygen/nitrogen species metabolism is involved in the tolerant response of the invasive plant species Ailanthus altissima to drought and salinity. Environmental and Experimental Botany, 97, 1-10. https://doi.org/10.1016/j.envexpbot.2013. 09.010

Giannopolitis, C. N., \& Ries, S. K. (1977). Superoxide dismutases. I Occurrence in higher plants. Plant Physiology, 59, 309-314. https://doi.org/10.1104/pp.59.2.309

Grieve, C. M., \& Grattan, S. R. (1983). Rapid assay for determination of water soluble quaternary ammonium compounds. Plant and Soil, 70, 303-307. https://doi.org/10.1007/BF02374789 
Hageman, R. H., \& Hucklesby, D. P. (1971). Nitrate reductase from righer plants. Methods in Enzymology, 17A, 491-503. https://doi.org/10.1016/S0076-6879(71)23121-9

Hopinks, H. C. F. (1986). Parkia (Leguminoseae: Mimosoideae) (Vol. 43, pp. 93-98). Flora Neotrópica. New York Botanical Garden, New York.

Jaleel, C. A., Manivannan, P., Sankar, B., Kishorekumar, A., Gopi, R., Somasundarum, R., \& Panneerselvan, R. (2007). Water deficit stress mitigation by calcium chloride in Catharanthus roseus: Effects on oxidative stress, proline metabolism and indole alkaloid accumulation. Colloids and Surfaces B: Biointerfaces, 60, 110-116. https://doi.org/10.1016/j.colsurfb.2007.06.006

Kant, S., Kant, P., Lips, H., \& Barak, S. (2007). Partial substitution of $\mathrm{NO}_{3}^{-}$by $\mathrm{NH}_{4}^{+}$fertilization increases ammonium assimilating enzyme activities and reduces the deleterious effects of salinity on the growth of barley. Journal of Plant Physiology, 164, 303-311. https://doi.org/10.1016/j.jplph.2005.12.011

Lea, P. J., \& Miflin, B. J. (2011). Nitrogen assimilation and its relevance to crop improvement. Annual Plant Reviews, 42, 1-40.

Li, S. X., Wang, Z. H., \& Stewar, B. A. (2013). Responses of crop plants to ammonium and nitrate N. Advances in Agronomy, 118, 205-397. https://doi.org/10.1016/B978-0-12-405942-9.00005-0

Loureiro, A. A, Freitas, J. A., Ramos, K. B. L, \& Freitas, C. A. A. (2000). Essências madeireiras da Amazônia (Vol. 4, p. 191). Manaus: MCT/ INPA/CPPF.

Marenco, R. A., \& Lopes, N. F. (2005). Fisiologia Vegetal: Fotossíntese, respiração, relações hídricas e nutrição mineral. Editora UFV, Viçosa, MG.

Matos, F. S., Oliveria, L. R., Freitas, R. G., Evaristo, A. B., Missio, R. F., \& Cano, M. A. O. (2012). Physiological characterization of leaf senescence of Jatropha curcas L. populations. Biomass and Bioenergy, 45, 57-64. https://doi.org/10.1016/j.biombioe.2012.05.012

Matos, F. S., Rosa, V. R., Borges, L. F. O., Ribeiro, R. P., Cruvinel, C. K. L., \& Dias, L. A. S. (2014). Response of Jatropha curcas Plants to Changes in the Availability of Nitrogen and Phosphorus in Oxissol. Journal of Academic Journals, 9, 3581-3586.

Mittler, R. (2002). Oxidative stress, antioxidants and stress tolerance. Trens in Plant Science, 7, $405-410$. https://doi.org/10.1016/S1360-1385(02)02312-9

Moller, I. M., Jensen, P. E., \& Hansson, A. (2007). Oxidative modifications to cellular components in plants. Annual Reviews Plant Biology, 58, 459-481. https://doi.org/10.1146/annurev.arplant.58.032806.103946

Munné-Bosch, S., Queval, G., \& Foyer, C. H. (2013). The Impact of Global Change Factors on Redox Signaling Underpinning Stress Tolerance. Plant Physiology, 161, 5-19. https://doi.org/10.1104/pp.112.205690

Munôz-Clares, R. A., \& Velasco-Garcia, R. (2004). Genio y figura de la betaína aldehído Deshidrogenasa. Mensaje Bioquímico, 28, 203-223.

Nakano, Y., \& Asada, K. (1981). Hydrogen-peroxide is scavenged by ascorbate-specifi c peroxidase in spinach-chloroplasts. Plant Cell Physiology, 22, 867-880.

Nascimento, H. H. C., Nogueira, R. J. M. C., Silva, E. C., \& Silva, M. A. (2011). Análise do crescimento de mudas de Jatobá (Hymenaea courbaril L.) em diferentes níveis de água do solo. Revista Árvore, 35, 617-626. https://doi.org/10.1590/S0100-67622011000400005

Oliveira, M. C. P., \& Ferraz, I. D. K. (2003). Comportamento das sementes de Parkia pendula (Wild.) Walp. (visgueiro) no banco de semente aéreo. In N. Higuch (Ed.), Projeto Jacarandá, fase II: Pesquisas florestais na Amazônia Central (pp. 103-116). Manaus: Coordenação de Pesquisas em Silvicultura Tropical, INPA.

Oliveira, M. C. P., Ferraz, I. D. K., \& Oliveira, G. J. de. (2006). Dispersão e superação da dormência das sementes de Parkia pendula (Wild.) Walp. (visgueiro) na Amazônia Central. Hoehnea, Água Funda, 33, 485-493.

Pavinato, P. S. (2008). Nitrogênio e potássio em milho irrigado: Análise técnica e econômica da fertilização. Ciência Rural, 38(2), 358-364. https://doi.org/10.1590/S0103-84782008000200010

Peoples, M. B., Faizah, A. W., Reakasem, B. E., \& Herridge, D. F. (1989). Methods for evaluating nitrogen fixation by nodulated legumes in the field (p. 76). Australian Centre for International Agricultural Research, Canberra. 
Pilon, M., Abdel-Ghany, S. E., Cohu, C. M., Gogolin, K. A., \& Ye, H. (2006). Copper cofactor delivery in plant cells. Curr. Opin. Plant Biol., 9, 256-263. https://doi.org/10.1016/j.pbi.2006.03.007

Pompeu, G. B., Gratão, P. L., Vitorello, V. A., Azevedo, R. A. (2008). Antioxidant isoenzyme responses to nickel-induced stress in tobacco cell suspension culture. Scientia Agricola, 65, 548-552. https://doi.org/ 10.1590/S0103-90162008000500015

Rhein, A. F. L., Santos, D. M. M., \& Carlin, S. D. (2011). Atividade da enzima redutase do nitrato e teores de prolina livre em raízes de cana-de-açúcar sob os estresses hídrico e ácido no solo. Ciências Agrárias, 32, 1345-1360. https://doi.org/10.5433/1679-0359.2011v32n4p1345

Rishi, A., \& Sneha, S. (2013). Antioxidative defense against reactive oxygen species in plantsunder salt stress. International Journal of Current, 5, 1622-7.

Sankar, B. (2007). Effect of paclobutrazol on water stress amelioration through antioxidants and free radical scavenging enzymes in Arachis hypogaea L. Colloids and Surfaces B: Biointerfaces, 60, 229-235. https://doi.org/10.1016/j.colsurfb.2007.06.016

Simova-Stoilova, L. (2009). Antioxidative protection and proteolytic activity in tolerant and sensitive wheat (Triticum aestivum L.) varieties subjected to long-term field drought. Plant Growth Regulator, 58, 107-117. https://doi.org/10.1007/s10725-008-9356-6

Slavick, B. (1979). Methods of studying plant water relations (p. 449). New York, Springer Verlang.

Soares, A. M. S., \& Machado, O. T. L. (2007). Defesa de planta: Sinalização química e espécies reativas de oxigênio. Revista Tropical, 1, 9-20.

Sood, A., Pabbi, S., \& Uniyal, P. L. (2011). Effect of paraquat on lipid peroxidation and antioxidant enzymes in aquatic fern Azolla microphylla Kual. Russ. J. Plant Physiol., 58, 667-673. https://doi.org/10.1134/S10214 43711040170

Szabados, L., \& Savouré, A. (2011). Proline: A multifunctional amino acid. Trends in Plant Science, 15, 89-97. https://doi.org/10.1016/j.tplants.2009.11.009

Turkan, I. (2011). Plant Responses to Drought and Salinity Stress: Developments in Post-Genomic Era. Advances in Botanical Research, 57, 593.

Weatherburn, M. W. (1967). Phenol hipochlorite reaction for determination of ammonia. Analytical Chemistry, 39, 971-974. https://doi.org/10.1021/ac60252a045

\section{Copyrights}

Copyright for this article is retained by the author(s), with first publication rights granted to the journal.

This is an open-access article distributed under the terms and conditions of the Creative Commons Attribution license (http://creativecommons.org/licenses/by/4.0/). 